\title{
Antimicrobial activity of peptides extracted from camels' blood neutrophils against some pathogenic bacteria
}

\author{
M.A. Mahmood ${ }^{1 \odot}$ and M.A. Essa ${ }^{2} \odot$ \\ ${ }^{1}$ Biology Department, College of Education Pure Sciences, ${ }^{2}$ Biology Department, College of Science, University of Mosul, \\ Mosul, Iraq
}

\author{
Article information \\ Article history: \\ Received November 11, 2019 \\ Accepted February 21, 2020 \\ Available online September 9, 2020 \\ Keywords: \\ Antimicrobial peptide \\ Multidrug-resistant \\ RP-HPLC \\ Radial diffusions method

\section{Correspondence:} \\ M.A. Essa \\ momo12345mola@gmail.com
}

\begin{abstract}
The aim of the current research was to isolate and purify antimicrobial cationic peptides (Amps) taken from camel blood and to study its antibacterial activity against some multidrug-resistant pathogenic bacteria Salmonella typhimurium, Bacillus subtilis. The results showed the possibility of obtaining these peptides from camel's white blood cells, and was separated by using Reversed-Phased-High Performance Liquid Chromatography (RP-HPLC) technical equipment. The results showed the presence of 21 absorption peaks of the isolated peptide extract. The two-stage-radial diffusions method was used to study the activity of the crude peptide against the studied bacteria. The results showed that these peptides were effective without any resistance. The best effect was on the Bacillus subtilis with a diameter of $31 \mathrm{~mm}$ inhibition, while the less effect was on the Salmonella typhimurium with a diameter of $20 \mathrm{~mm}$.
\end{abstract}

DOI: 10.33899/ijvs.2020.126239.1270, C2021, College of Veterinary Medicine, University of Mosul.

This is an open access article under the CC BY 4.0 license (http://creativecommons.org/licenses/by/4.0/).

\section{Introduction}

Antimicrobial peptides (Amps) are defined as the total host defense peptides in the various organisms that enter into innate immunity, which response to any external or environmental effect $(1,2)$. These peptides have a high ability to kill different types of Gram-positive and negative bacteria, including bacteria that showing resistance to antibiotics, as well as fungi, viruses and even cancer cells (3). These peptides are advanced therapeutic agents and differ from the used-antibiotics according to their affinity to be more bactericidal than bacteriostatic against bacteria, and the inability of bacteria to develop resistance towards them compared to antibiotics (4).

Many types of antimicrobial peptides are isolated from different sources, both plant and animal, or from some prokaryotic organisms. Mammalians blood is one of the best sources for isolation of these peptides. They are isolated from leukocytes, especially neutrophils, in some animals such as cattle, sheep, goats, deer and pigs $(5,6)$. They are generally divided into two main groups: cationic peptides and anionic peptides $(7,8)$. Positive types are the most effective group against the various pathogens of humans, which have two important groups: Defensins and Cathelicidins, that are divided into several secondary types according to their forms and structures (9).

Each group differ from other one in their shape, but both have positive charge, hydrophobic, and the same mechanism of action by binding to cell walls and plasma membranes with changing in their structures, engineering and loss functions (10-12). The negatively charged group (Anionic) of antimicrobial peptides is usually much smaller than positive peptides (Cationic) and has a little number of peptides that have weak and unclear antimicrobial activity against pathogens (13). Due to the importance of these antibacterial peptides as effective therapeutic alternatives, the present study aimed to extract these peptides from the white blood cells of camels and study their antimicrobial activity against Gram-examples of positive and negative bacteria that have multidrug resistance property. 


\section{Materials and methods}

\section{Bacterial isolates}

Two types of isolated pathogenic bacteria Salmonella typhimurium and Bacillus subtilis which isolated and diagnosed previously in the Department of Biology at the College of Education for Pure Sciences at University of Mosul.

\section{The animal used}

A single-humped camel Camels dromedarius was used in this search which is locally bred in Nineveh province to obtain blood sample.

\section{Preparing cultivation media}

The cultivation media used to study sensitivity of bacteria against Amps using the Two-stage radial diffusion method, were prepared from their initial components according to (14).

\section{Antibiotics \\ Ten disks of antibiotics were used-manufactured by

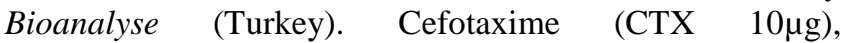 ciprofloxacin (CIP $10 \mu \mathrm{g}$ ), streptomycin (S $10 \quad \mu \mathrm{g})$, doxycycline (DO $10 \mu \mathrm{g}$ ), ampicillin (AM $10 \quad \mu \mathrm{g}$ ), amoxiclave (AMC $30 \mu \mathrm{g}$ ), norfloxacin (Nor $10 \mu \mathrm{g}$ ), tetracycline (TE $30 \mu \mathrm{g}$ ), gentamycin (GN $30 \mu \mathrm{g}$ ), naldixic acid (NAI $30 \mu \mathrm{g}$ ). \\ Collecting blood \\ Approximately $300 \mathrm{ml}$ of camel venous blood was collected, mixed directly with sodium citrate solution to prevent clotting 1:4 of blood and shaken well to prevent coagulation until use in subsequent experiments (15).}

\section{Isolating and extracting of antimicrobial peptides from leukocytes}

The method was based on $(6,14)$, where Amps were isolated from a camel's leukocytes. Briefly, the red blood cells were lysed by the addition of $0.83 \%$ ammonium chloride solution to the blood at a ratio of 3:1 (ammonium chloride: blood). White blood cells were collected by centrifugation at $700 \times \mathrm{g}$ for $15 \mathrm{~min}, 4{ }^{\circ} \mathrm{C}$, re-suspended in phosphate buffer saline and sonicated to release the neutrophil granules. These granules were collected by centrifugation at $27,000 \times \mathrm{g}$ for $40 \mathrm{~min}, 4^{\circ} \mathrm{C}$, and suspended in $10 \%$ acetic acid and mixed overnight at $4^{\circ} \mathrm{C}$ to extract the antimicrobial peptides. The solution containing the antimicrobial peptides was separated from the granules by centrifugation at $27,000 \times \mathrm{g}$ for $20 \mathrm{~min}, 4^{\circ} \mathrm{C}$. The extract was lyophilized, dissolved in $0.01 \%$ acetic acid and stored at -70 ${ }^{\circ} \mathrm{C}$ until use.

\section{Purifying cationic Amps using ion exchange technique}

The cationic Amps were purified from the solution according to $(6,14)$, by ion-exchange chromatography technique. Amberlite resin IRC-50 (H) column was used, and the cationic Amps bound to the anionic resin and the non-cationic molecules were washed with $25 \mathrm{~m} \mu$ ammonium acetate, then the cationic Amps were eluted with 10\% acetic acid. The solution was pumped through the column at a rate of $20 \mathrm{ml} / \mathrm{h}$. The cationic Amps was Lyophilized and kept until use.

Isolating the cationic peptides by using Reversed PhasedHigh Performance Chromatography

The method was conducted according to $(14,16)$, and the cationic peptides were isolated from the camel by using HPLC (Japan / Shimadzu-2010A) with isolating column type and size R.P C18, with non-polar Stationary Phase, with polar Mobile phase, with gradual rate of Acetonitrile from 1 to $60 \%$, trifluoroacetic acid (TFA) and distilled water.

\section{Antimicrobial activity of isolated cationic peptides}

The antibacterial activity of isolated cationic Amps against the bacteria was studied according to the updated (16) method, where the two-stage radial diffusions method of (17) was used.

\section{The Antibiotics sensitivity test}

Antibiotics sensitivity test against studied bacterial isolates was conducted according the modified method of Kirby-Bauer, (18).

\section{Results}

\section{The Antibiotics sensitivity test}

The results of the bacterial isolates sensitivity (Salmonella typhimurium and Bacillus subtilis) to a group of antibiotics were showed in table 1 , where contrasts between these isolates can be noticed in the manner of their resistance for antibiotics. Bacillus subtilis showed resistance for most antibiotics under study, it was sensitive only for four antibiotic ciprofloxacin, tetracycline, gentamycin and amoxicillin with clavulanic acid, while Salmonella typhimurium was resistant for all types of antibiotics except gentamycin and ciprofloxacin.

\section{Purifying and isolating the cationic peptides}

The results in Figure 1 show that there are a large number of peaks, which are due to the solution of these peptides, which can represent the different types of cationic peptides present in the extract, which is isolated from camel blood, it is observed to have 21 peaks of absorption or peptide type of cationic peptides, which differed from each other in retention time of each species, and the percentage of high and area. The larger peak appeared in the retention time of 1.523 minutes, with a percentage of high $26.281 \%$ and a percentage of area $22.077 \%$, which is discriminate on other cationic peptides that have emerged in this solution, and was the smallest peak, which appeared in the retention time of 11.028 
minutes and at the height of $0.018 \%$ and the percentage of the area $0.017 \%$.

Table 1: Results of the studied bacterial isolates sensitivity (Diameter of inhibition in $\mathrm{mm}$ )

\begin{tabular}{lcc}
\hline \multirow{2}{*}{ Antibiotics $(\mu \mathrm{g})$} & \multicolumn{2}{c}{ Bacteria } \\
& Bacillus subtilis & S. typhimurium \\
\hline Cefotaxime (10) & $\mathrm{R}$ & $\mathrm{R}$ \\
Ciprofloxacin (10) & $\mathrm{S}(26)$ & $\mathrm{S}(24)$ \\
Streptomycin (10) & $\mathrm{R}$ & $\mathrm{R}$ \\
Doxycycline (10) & $\mathrm{R}$ & $\mathrm{R}$ \\
Ampicillin (10) & $\mathrm{R}$ & $\mathrm{R}$ \\
Amoxiclave (30) & $\mathrm{S}(25)$ & $\mathrm{R}$ \\
Norfloxacin (10) & $\mathrm{R}$ & $\mathrm{R}$ \\
Tetracycline (30) & $\mathrm{S}(25)$ & $\mathrm{R}$ \\
Gentamycin (30) & $\mathrm{S}(27)$ & $\mathrm{S}(22)$ \\
Naldixic acid (30) & $\mathrm{R}$ & $\mathrm{R}$ \\
\hline
\end{tabular}

$\mathrm{S}=$ Sensitive, $\mathrm{R}=$ Resistant

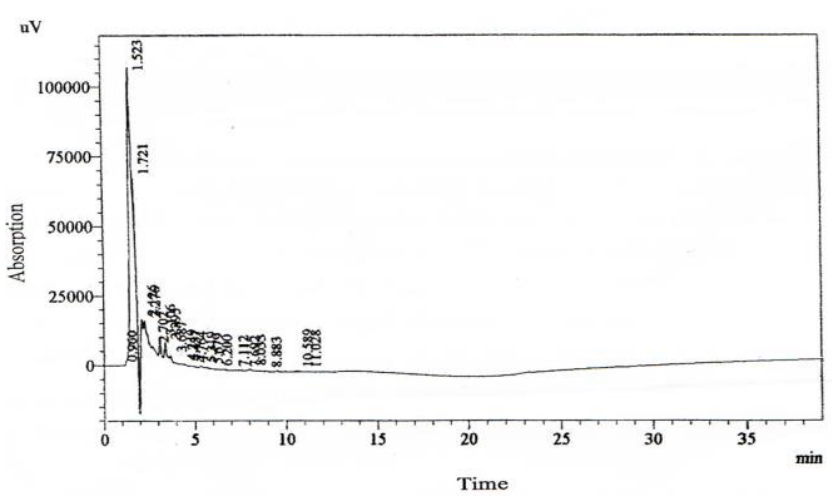

Figure 1: Shows the absorption peaks of the isolated cationic peptides from camels' blood using RP-HPLC.

\section{Antimicrobial activity of the isolated cationic peptides}

The results in table 2 and figure 2 show that the cationic peptides isolated from the camel blood had an antiviral effect against the bacteria under study despite their multiple resistance to antibiotics.

Table 2: The antibacterial activity of the cationic peptides on pathogenic bacteria under study (Diameter of inhibition in $\mathrm{mm})$

\begin{tabular}{lcc}
\hline Bacteria type & Bacillus subtilis & S. typhimurium \\
\hline Inhibiting effect & 31 & 20 \\
\hline
\end{tabular}

The positive peptides isolated from the camel blood have a distinct effect on the two types of bacteria under study, and it is generally observed that the effect of these peptides was more effective in the Gram-positive bacteria compared to the gram-negative bacteria; it is noted that it has a greater effect on Bacillus subtilis with an inhibition zone $31 \mathrm{~mm}$, compared to Salmonella typhimurium with an inhibition zone of $20 \mathrm{~mm}$.
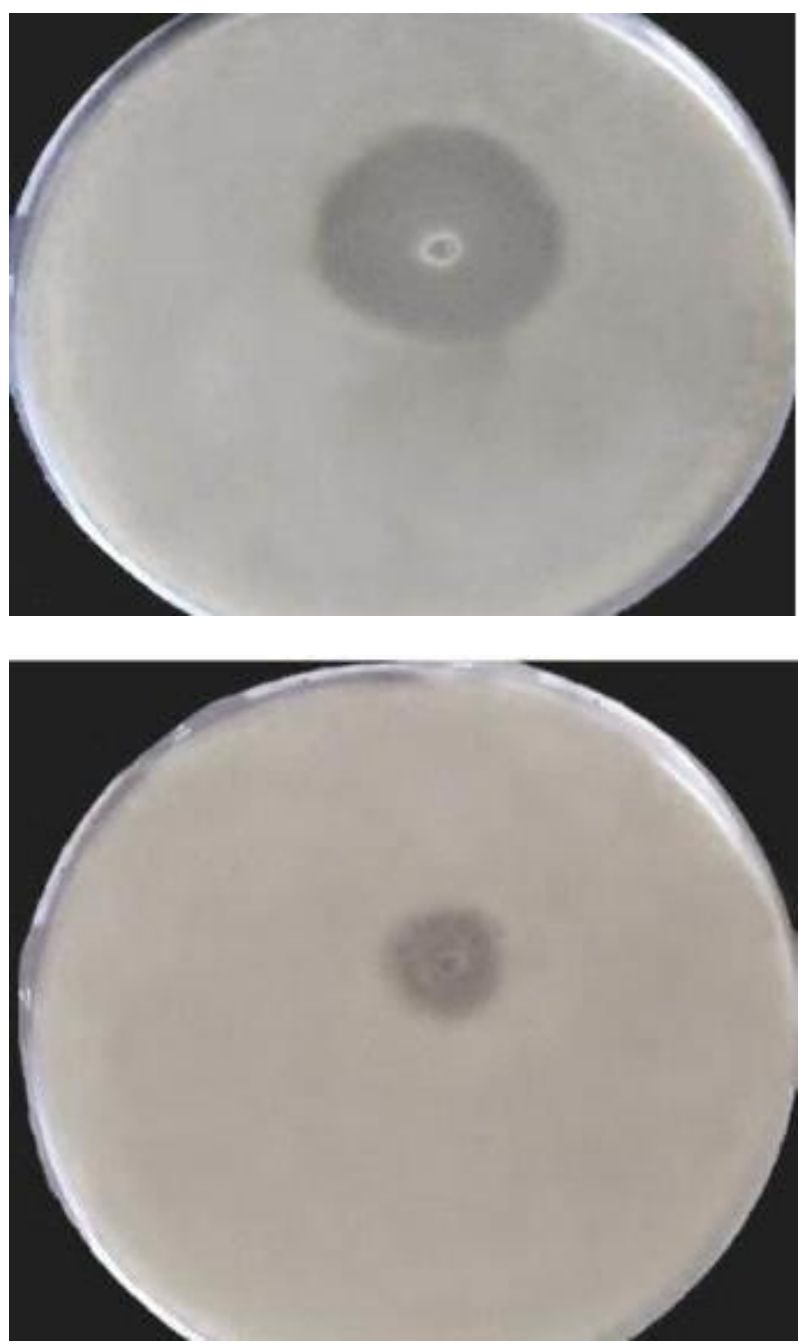

Figure 2: Antimicrobial activity of the isolated cationic peptides on pathogenic bacteria. (A) Bacillus subtilis (B) Salmonella typhimurium.

\section{Discussion}

In general, it is noticed that through these results the bacteria showed various levels of resistance for antibiotics. The emergence of bacteria resistant to traditional antibiotics is a common health problem and a serious challenge for specialists in this field, where the problem has increased dramatically and rapidly in recent decades with a decrease in the number of new antibiotics detected and increase the need for therapeutic alternatives $(2,19)$. Cationic peptides were chosen because of the importance of this type of antibacterial peptides and their effective role in killing of many pathogenic microorganisms compared with other types of 
these peptides found in the blood of different animals. While, the non-cationic peptides are less significant and less important in the bacterial study and fewer and less diverse $(7,13)$. This technique is based on the principle of ion exchange, gravitational processes and the opposite adhesion between the components of the insulating material with the materials used in the separation column and by the charge and its strength, the technique has been used by researchers in the field of isolation and purification of peptides from the blood of different animals $(6,20)$. So it was observed that the large number of peptides isolated from the camel blood, with noting differences in the characteristics of the retention time and the proportion of the height and area and the emergence of the number of these peptides isolated from the camel blood may be due to the physiology of the camel and its environment where it lives, may reflect the evolution of its immunity and its mechanisms of resistance to pathogenic microorganisms if we consider that these peptides are isolated from white blood cells with defensive function in the body. The two-stage radial diffusion method was used for it is sensitive and important when studying the inhibiting effect of the isolated cationic peptides from camels' blood on two kinds of pathogenic bacteria (Salmonella typhimurium and Bacillus subtilis) which are known as resistant of antibiotics drugs as shown in table 1. Salmonella typhimurium is one of the bacterial serovars responsible for human and animal infections, as well as noted the increasing rate of antibiotic resistance of Salmonella typhimurium, and the ability to form endospore by Bacillus subtilis allows increasing of bacterial resistance and survival (21-23). These peptides have a positive charge that reacts and attracts the negative charge bacterial cell membranes and cell walls, as well as the presence of special receptors for these peptides on the bacterial cell walls. This correlation and interaction lead to major changes in the structure and engineering of bacterial cell walls and their membranes leading to their death, as well as other effective mechanisms for these peptides $(24,25)$. Where (26) explained that the peptide (Bac5), which is considered from positive peptides that isolated from the blood of mammalian animals, had a significant effect in several types of gram-positive bacteria, and a less effect in the Gram-negative bacteria and this corresponds to the results obtained in this research.

These results may be due to the difference between the cell wall of gram-positive bacteria and gram-negative bacteria, and the effect of these peptides is mainly on the walls and cellular membranes of the bacteria. The increase in the effect of cationic peptides isolated from camel's blood may be due to the number of peptides in the blood of camels, where approximately 21 different peaks.

The importance of the current research results in the possibility of putting these peptides as drug alternatives to control the diseases associated with these studied bacteria and others, after conducting appropriate studies to ensure effective and safety, and there is a need for more comprehensive and detailed studies dealing with other types of animals as well as bacteria to show the importance of these peptides in the treatment of diseases associated with these bacteria, especially, those resistant to the antibiotics.

\section{Conclusion}

The results of isolating and purifying of Amps showed the possibility of obtaining Amps from blood of camel, and the result of antimicrobial activity of these isolated peptides against studied pathogenic bacteria, showed that these peptides were effective and there was no resistance against them.

\section{Acknowledgements}

The authors are very grateful to the University of Mosul, College of Education Pure Science, Biology Department, and College of Veterinary Medicine for their provided facilitates, which helped to improve the quality of this work.

\section{Conflict of interest}

The authors declare that there is no conflict of interest.

\section{References}

1. Wang G. Antimicrobial peptides discovery, design and novel therapeutic strategies: Advances in molecular and cellular Microbiology 18. USA: University of Nebraska medical center Omaha; 2010. 1-21 p. DOI:10.1097/9781845936570.0000

2. Oliveria SMS, Falcao-Silva VS, Siqueira-Junior JP, Costa MJD, Dinix MDF. Modulation of drug resistance in Staphylococcus aureus by extract of mango (Mangifera indical L., Anacardiaceae) peel. Rev Bras Farmac. 2011;21(1):1-5. doi: 10.3390/molecules16032023

3. Epand RM, Epand RF. Biophysical analysis of membrane- targeting antimicrobial peptides: Membrane properties and the design of peptides specifically targeting gram-negative bacteria. USA: University of Nebraska medical center Omaha; 2010. 116-126 p. DOI: $10.1002 /$ psc. 1319

4. Langham AA, Ahmad SA, Kaznessis YN. On the nature of antimicrobial activity: A model for Protegrin-1 pores. J Am Chem Soc. 2008;130(13):4338-4346. Doi: 10.1021/ja0780380

5. Anderson RC, Hancock REW, Yu PL. Antimicrobial activity and bacterial membrane interaction of ovine-derived cathelicidinins. Antimicrob Agents Chemother. 2004;48:673-676. Doi: 10.1128\%2FAAC.48.2.673-676.2004

6. Treffers H, Chen L, Anderson RC, Yu P. Isolation and characterization of antimicrobial peptides from deer neutrophils. J Intern Antimicrob Agent. 2005;26(2):165-169. Doi: 10.1016/j.ijantimicag.2005.05.001

7. Anderson RC, Wilkinson B, Yu P. Ovine antimicrobial peptides, new products from an age-old industry. Aust J Agr Res. 2004;55(1):96-75. Doi: 10.1071/EA07185

8. Kumar P, Kizhakkedathu JN, Straus SK. Antimicrobial peptides diversity, mechanism of action and strategies to improve the activity and biocompatibility in vivo. J Biomolecules. 2018;1-24. Doi: 10.3390\%2Fbiom8010004

9. Brogden KA. Antimicrobial peptides: pore formers or metabolic inhibitors in bacteria. Nat Rev Microb. 2005;3(3):238-250. Doi: $\underline{10.1038 \text { nrmicro1098 }}$ 
10. Zhao C, Ganz T, Lehrer RI. Structure of genes for two cathelinassociated antimicrobial peptide: Prophenin-2 and PR-39. Letters. 1995;376(3):130-134. Doi: 10.1016/0014-5793(95)01237-3

11. Huttner KM, Lambeth MR, Burking HR, Burkin DJ, Broad TE. Localization and genomic organization of sheep antimicrobial peptide genes. Gene. 1998;206(1):85-91. Doi: 10.1016/S0378-1119(97)005696

12. Matsuzaki K. Antimicrobial Peptides. Springer nature Switzerland AG. 2018. ISBN 978-981-13-3588-4. Doi: 10.1007/978-981-13-3588-4

13. Brogden KA, Ackermann M, McCray PB, Tack BF. Antimicrobial peptides in animals and their role in host defenses. J Intern Antimicrob Agents. 2003;22(5):465-478. Doi: 10.1016/s0924-8579(03)00180-8

14. Shamova O, Brogden KA, Zhao H, Nguyen T, Kokryakov VN, Lehrer R. Purification and properties of proline-rich antimicrobial peptides from sheep and goat leukocytes. Infect Immun. 1999;67(8):4106-4111. PMID: 10417180

15. Ghai CL. A text book of practical physiology. $6^{\text {th }}$ ed. New Delhi: Jaypee brothers-medical publishers Ltd; 2005. 1-25 p.

16. Selsted ME, Tang Y, Morris W, McGure PA, Novotny MJ, Smith W, Henschen AH, Cullor JS. Purification, primary structures, and antibacterial activities of B- defensins, a new family of antimicrobial peptides from bovine neutrophils. J Biol Chem. 1993;268(9):66416648. doi: $10.1074 / \mathrm{jbc} .271 .27 .16430$

17. Lehrer RI, Rosenman M, Harwing SSL, Jackson R, Eisenhauer P. Ultrasensitive assay for endogenous antimicrobial polypeptides. J Immuno Methods. 1991;137:167-173. Doi: 10.1016/00221759(91)90021-7

18. Vandepitte J, Engback K, Piot P, Heuk CC. Basic Laboratory procedures in clinical bacteriology. Geneva; World Health Organization; 2003. 1-19 p.

19. Sergio HM, Gloria A. Antimicrobial peptides: A natural alternative to chemical antibiotics and a potential for applied biotechnology. Electron J Biotechnol. 2003;19:271-282. Doi: 10.2225/vol6-issue3-fulltext-1

20. Anderson RC, Yu P. Isolation and characterization of proline argininrich chathelicidin peptides from ovine neutrophils. Bioch Bioph Re Comm. 2003;321(13):1139-1146. Doi: 10.1016/j.bbrc.2003.11.045

21. Saleh ZF, AL-Muhana BM, Hamdan Kh, Jawad MS, Klaif SF. Isolation and identification of Salmonella typhimurium bacteria with detection of type-1 fimbriae coding gene by polymerase chain reaction (PCR) technique. Iraqi J Vet Sci. 2019;33(1):195-199. Doi: 10.33899/ijvs.162961.2019

22. Ulrich N, Nagler K, Laue M, Cockell CS, Setlow P, Moeller R. Experimented studies addressing the longevity of Bacillus subtilis spores-the first data from a 500-year experiment. J PLoS Org Biol. 2018;10:1371. Doi: 10.1371/journal.pone.0208425

23. Sabri JB, Al-sultan II, Altaif K, Peter S, Saadh MJ. Pathogenesis of Salmonella enterica serovar Albany in experimental infected SPF
BALB/c Mice. Iraqi J Vet Sci. 2020;34(2):339-344. Doi: 10.33899/ijvs.2019.126269.1282

24. Pelegrinl PB, Delsarto RP, Silva ON, Franco OL, Grossi MF. Antibacterial peptides form plants: What they are and how they probably work. Bioch Res Intern. 2011;9:1155. Doi: $10.1155 / 2011 / 250349$

25. Li Z, Hu Y, Yang Y, Lu Z, Wang Y. Antimicrobial resistance in livestock: Antimicrobial peptides provide a new solution for a growing challenge. Anim Frontiers. 2018;8(2):1-9. Doi: 10.1093/af/vfy005

26. Collee JG, Fraser AG, Marmion BP, Simmon A. Practical medical microbiology. $14^{\text {th }}$ ed. New York: Churchill Livingstone; 1996.7:876.

\section{فعالية البيتيدات المضادة للجراثيم المعزولة من الخلايا العدلة لام الجمال تجاه بعض البئل الجراثيم الممرضة محمد عبدالله محمود' و محسن أيوب عيسى'}

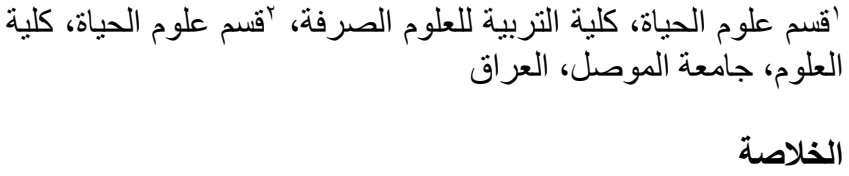

اجري هذا البحث بهدف عزل وتنقية البيتيدات الموجبة المضـادة للجر اثثم

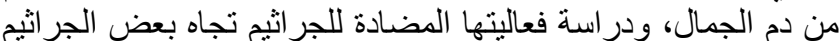

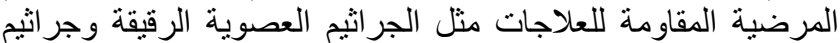
السالمونيلا تيفوئيد ومقارنة التأثثر مع مجمو عة من المضية المضادات الحيوية.

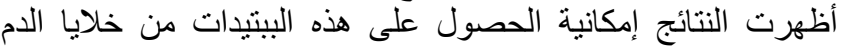

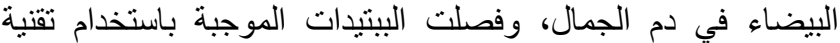

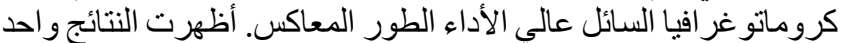

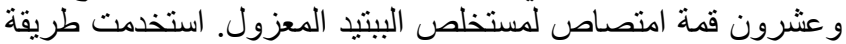
الانتشار الشعاعي ذو الطبقتين لدر اسة فعالية البيتيد الخام تجاه البكتريا

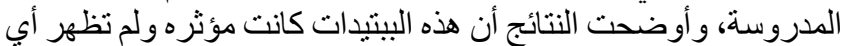

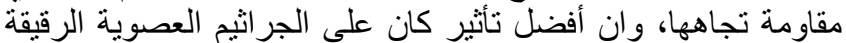
بقطر تثبيط اس ملم، بينما التأثثر الأقل نسبيا كان على على جر اثيم السالمونيلا

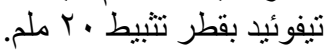

